\title{
The use of RAPD markers for the identification of Sitka spruce (Picea sitchensis) clones
}

\author{
WILHELMINA T. G. VAN DE VEN* \& RONNIE J. McNICOL \\ Scottish Crop Research Institute, Invergowrie, Dundee DD2 5DA, Scotland, U.K.
}

\begin{abstract}
DNA from 57 superior clones was amplified using arbitrary primers in the polymerase chain reaction, in order to assess the genetic variation within Sitka spruce and to investigate if individual clones could be identified. Six out of 30 primers gave reproducible banding patterns. Twenty-four polymorphic bands were scored for the 57 clones studied and all the clones could be identified using a combination of four or more primers. Nei's estimate of similarity was calculated and cluster analysis was used to generate a dendrogram showing considerable variation among the superior trees. Clonally produced material (ramets) could be recognized and mislabelled ramets were identified.
\end{abstract}

Keywords: clone identification, Picea sitchensis, RAPDs, Sitka spruce.

\section{Introduction}

Sitka spruce (Picea sitchensis (Bong.) Carr.) was introduced into Britain around the 1830 s from N. America, mainly from Washington and Oregon. The Forestry Authority later imported material from British Columbia, in particular from the Queen Charlotte Islands, which have similar climatic and ecological conditions to Britain. Sitka spruce adapted very well and is now one of the most important species grown in Britain (Rook, 1992). In breeding programmes only superior trees are used as parents. These are selected from stands and plantations around Britain on criteria such as growth-form, height, straightness, branching habit, disease resistance and timber quality. Selected trees are tested in progeny trials and those of superior genetic potential are kept. Cuttings from these trees are grafted on seedling root stocks (ramets) before they are planted in seed orchards, from which the seed for commercial plantations is produced. A seed orchard consists of a large number of clones, represented by several, widely separated, ramets. Although the resulting seed crop is expected to reflect both the genetic superiority and broad genetic base present among the orchard clones (Adams \& Joly, 1980), little is known about the genetic variation available. Variation at provenance and clonal level has been found in Sitka spruce using phenolics and terpene analysis (Forrest,

*Correspondence.
1994). In a recent study on outcrossing rates in Sitka spruce using six polymorphic allozymes only 42 per cent of 45 clones representing one seed orchard could be identified (Cottrell \& White, pers. comm.).

Molecular markers have proven to be very useful in distinguishing among related genotypes. For fingerprinting crop plants restriction fragment length polymorphisms (RFLPs) have been used extensively (Helentjaris \& Burr, 1989). Fingerprints have also been obtained with rDNA (Karvonen \& Savolainen, 1992), minisatellite (Nybom et al., 1990) and microsatellite (Volkaert et al., 1992) DNA sequence variation.

Recently, polymerase chain reaction (PCR) based methods have been used for identification purposes. These methods do not involve labelling of probes, are thus less time consuming and require much less starting material. In PCR, either known DNA sequences (Bousquet et al., 1990; D’Ovidio et al., 1990) or random DNA sequences (Williams et al., 1990) are amplified. Wilde et al. (1992) could distinguish 13 Theobroma clones using 14 random amplified polymorphic DNA (RAPD) primers. RAPD markers have also been used in other species to distinguish among cultivars, e.g. Rubus (Graham et al., 1994) and to assess the genetic polymorphism available in Pinus leucodermis (Morgante et al., 1992), Picea abies (Skov \& Wellendorf, 1992) and Quercus spp. (Moreau et al., 1992).

In this study RAPD markers were used to assess the genetic diversity of the clones within two seed orchards 
and to find markers that would distinguish among clones.

\section{Materials and methods}

\section{Plant material}

Young shoots were collected from 55 Sitka spruce clones grown in two seed orchards (12 and 13), which were planted in 1981-83 and 1984-85 at Ledmore, Perthshire, Scotland, U.K. Young shoots were also collected from five ramets of each of five clones (94, $140,1350,1427$ and 1609), grown in container pots at the Forestry Authority, Northern Research Station, Roslin, Midlothian, Scotland, U.K. Clones 94, 140 and 1350 were also among the 55 clones from the orchard.

\section{DNA isolation}

DNA was isolated from needles according to the method used by Bousquet et al. (1990). Some modifications were made: in the extraction buffer $\beta$ mercaptoethanol ( 0.2 per cent) was replaced by DTT ( 0.1 per cent) which is less harmful, and an additional phenol/chloroform/iso-amyl-alcohol extraction and RNase treatment at $70^{\circ} \mathrm{C}$ for 15 min were performed to purify further the DNA.

\section{DNA amplification}

Thirty random 10-mer oligonucleotides OPA-01 to OPA-20 (Operon Technologies Inc.) and SC10-01 to SC10-10 (Graham et al., 1994) were used in a PCR according to Williams et al. (1990). Reactions were carried out in $50 \mu \mathrm{L}$, each containing $15 \mathrm{ng}$ genomic DNA, $200 \mu \mathrm{M}$ of each of dNTP, $0.2 \mu \mathrm{M}$ primer, 0.8 unit Taq-polymerase and $1 \times$ reaction buffer (Boehringer Mannheim) or $15 \mathrm{ng}$ genomic DNA, $200 \mu \mathrm{M}$ of each of $\mathrm{dNTP}, 0.2 \mu \mathrm{M}$ primer, 1 unit Taq-polymerase, $1 \times$ reaction buffer, $1.5 \mathrm{mM} \mathrm{MgCl}$ and 0.05 per cent $\mathrm{W}-1$ (detergent) (GIBCO-BRL). Reactions were overlaid with $50 \mu \mathrm{L}$ mineral oil to prevent evaporation. DNA was amplified in a thermal cycler (Omni Gene, Hybaid) using the following programme: $1 \mathrm{~min}$ at $92^{\circ} \mathrm{C}, 1.5 \mathrm{~min}$ at $35^{\circ} \mathrm{C}$ and $2 \mathrm{~min}$ at $72^{\circ} \mathrm{C}$ for 45 cycles followed by an additional $5 \mathrm{~min}$ at $72^{\circ} \mathrm{C}$. The amplified samples were kept at $4^{\circ} \mathrm{C}$ before separation on 1.5 per cent agarose gels. Fragments were visualized under UV light after staining with ethidium bromide. All reactions were triplicated and only reproducible bands were considered in this study.

\section{Analysis}

The gels were scored for the presence or absence of a certain fragment and the data were analysed using Nei's similarity index: $\left(S_{\mathrm{AB}}=2 N_{\mathrm{AB}} /\left(N_{\mathrm{A}}+N_{\mathrm{B}}\right)\right)$, where $N_{\mathrm{AB}}$ is the number of shared fragments, $N_{\mathrm{A}}$ the number of fragments from clone $\mathrm{A}$, and $N_{\mathrm{B}}$ the number of fragments from clone B (Nei \& Li, 1979). Average linkage cluster analysis was performed based on Nei's similarity index and the calculations were carried out using GENSTAT 5.2.

\section{Results}

Thirty 10-mer oligonucleotides were tested for their capacity to differentiate among five Sitka spruce clones, 94, 140, 1350, 1427 and 1609. Eleven of the primers gave similar banding patterns for all five clones. Eight primers gave either no bands or polymorphism occurred only in faint unreproducible bands. Five primers gave very complex banding patterns, and six primers gave reproducible banding patterns by which the five clones could be distinguished. These six primers produced four to eight scorable bands (Table 1).

Table 1 Sequences of the six useful primers, with the number of scorable amplified and polymorphic bands

\begin{tabular}{llcc}
\hline Primer & Sequence & $\begin{array}{c}\text { No. amplified } \\
\text { bands }\end{array}$ & $\begin{array}{c}\text { No. polymorphic } \\
\text { bands }\end{array}$ \\
\hline SC10-02 & GGTCCTCAGG & 5 & 2 \\
SC10-09 & CAGTTCTGGC & 8 & 4 \\
OPA-08 & GTGACGTAGG & 4 & 3 \\
OPA-09 & GGGTAACGCC & 6 & 4 \\
OPA-18 & AGGTGACCGT & 7 & 7 \\
OPA-19 & CAAACGTCGG & 8 & 4 \\
& & 38 & 24 \\
\hline
\end{tabular}




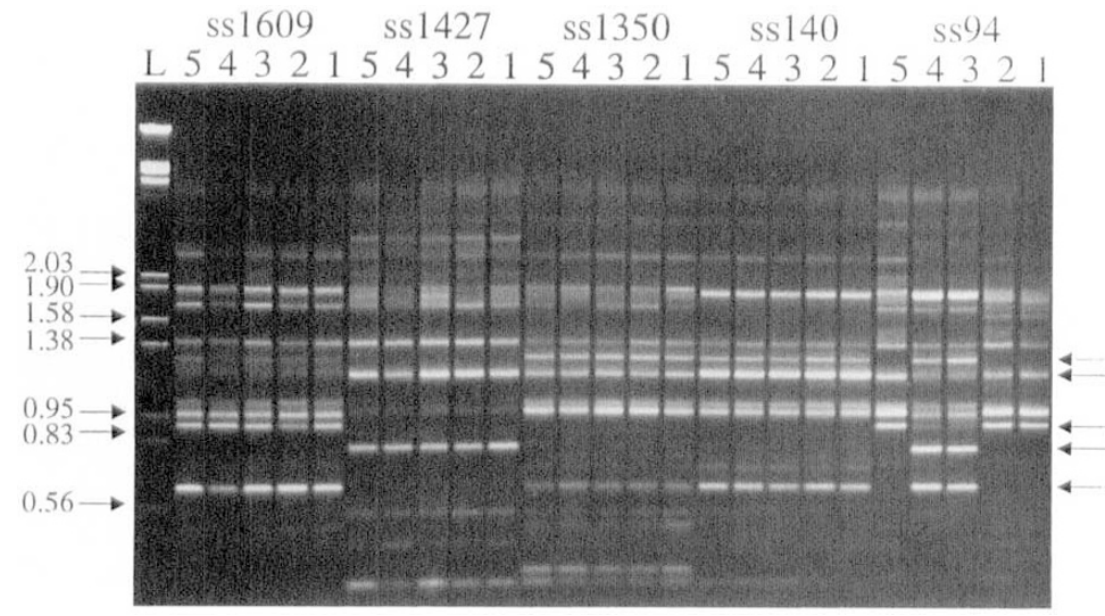

Fig. 1 Amplification patterns obtained from five ramets $(1-5)$ of each of five Sitka spruce clones (1609-94) using primer OPA-19. L: lambda EcoRI/ HindIII size maker (in kb); $\leftarrow$ : scorable informative bands.
The six selected primers were used in combination with two Taq-polymerase enzymes (Boehringer Mannheim and GIBCO-BRL). The two Taq-polymerase sources, used with their own buffers, proved to give similar patterns. Only a few differences were found in faint bands, which did not affect our scoring.

The reproducibility of RAPD markers over vegetatively multiplied material was assessed by using the selected six primers on five ramets of each of the above-mentioned five Sitka spruce clones (Fig. 1). Ramets 3 and 4 from clone 94 showed similar banding patterns, but different banding patterns from ramets 1 , 2 , and 5 from the same clone. This was also found with the other five primers. The banding patterns generated by each primer from the five ramets of the other clones, $140,1350,1427$ and 1609, were identical. For further analysis ramets 3 and 4 from clone 94 will be considered as clone 94a and ramets 1,2 and 5 as clone 94b. Also clones 140 and 1350 will be considered as $140 \mathrm{a}$ and $1350 \mathrm{a}$ to distinguish them from the same clones in the seed orchard.

A total of 57 clones, representing the clones in two seed orchards and two additional clones, were analysed using the six primers. They generated 38 reproducible bands of which 14 were consistent in all clones and 24 were polymorphic, giving a mean of four polymorphic bands per primer. The polymorphic bands and their sizes are given in Table 2.

All 57 clones were scored for the presence or absence of the 24 bands and the data obtained were analysed using cluster analysis. The cluster analysis produced both a dendrogram (Fig. 2) and a bandmap (Fig. 3). The similarities among the Sitka spruce clones range from 38 to 96 per cent (data not shown). The dendrogram shows clone 1100 as the most divergent; it joins the other clones at 45 per cent similarity. The most similar at 95 per cent were clones 1101 and 94,
Table 2 Polymorphic bands and their molecular size

\begin{tabular}{ccr}
\hline Band & Primer & Size (in bp) \\
\hline 2.1 & SC10.02 & 1600 \\
2.2 & & 750 \\
9.1 & SC10-09 & 1640 \\
9.2 & & 1140 \\
9.3 & & 1130 \\
9.4 & OPA-08 & 930 \\
A8.1 & & 2180 \\
A8.2 & & 1160 \\
A8.3 & OPA-09 & 1090 \\
A9.1 & & 930 \\
A9.2 & & 800 \\
A9.3 & & 620 \\
A9.4 & OPA-18 & 580 \\
A18.1 & & 1560 \\
A18.2 & & 1300 \\
A18.3 & & 1220 \\
A18.4 & & 970 \\
A18.5 & & 760 \\
A18.6 & & 710 \\
A18.7 & & 480 \\
A19.1 & & 1270 \\
A19.2 & OPA-19 & 1180 \\
A19.3 & & 890 \\
A19.4 & & 620 \\
\hline
\end{tabular}

and 1102 and 1713. The dendrogram could be divided into six clusters at 70-75 per cent similarity, and the majority of the clones join together at 60 per cent similarity.

The bandmap gives a graphical presentation of the original data (Powell et al., 1991). The order of the clones, on the left, is a result of cluster analysis of the similarity indices calculated, placing genotypes with 


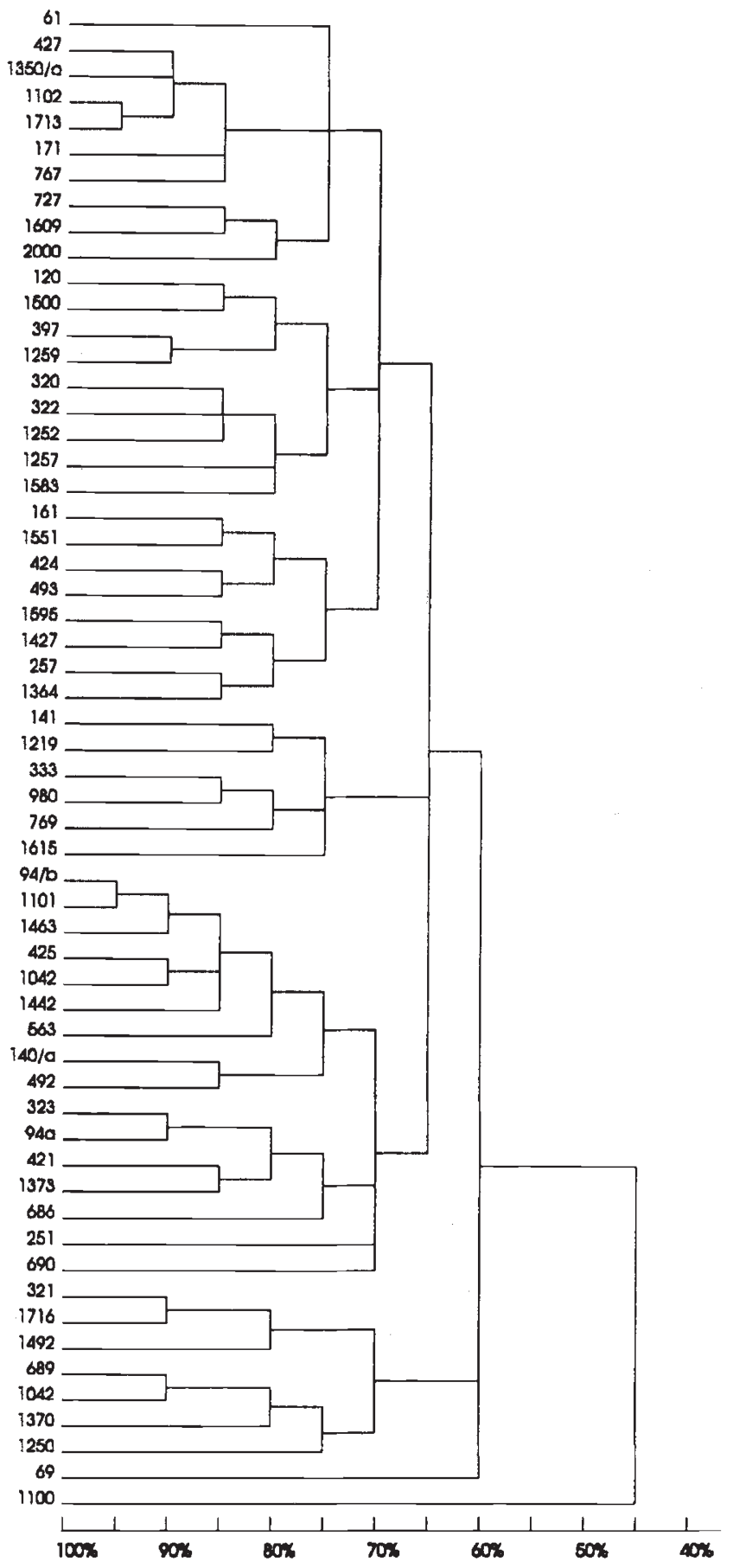

Fig. 2 Dendrogram generated after cluster analysis based on Nei's similarity index of RAPD data.

higher similarity next to each other. The numbers at the top represent the individual 24 polymorphic bands (see band no. in Table 2) which have been arranged according to their frequency (number at the bottom). The stars on the right indicate if two adjacent clones are in fact identical with respect to their amplification products. As mentioned before clones 1102 and 1713 are very similar ( 95 per cent) and are thus placed next to each other. Clones 94 and $94 \mathrm{~b}$ are placed next to each other and are in fact identical, indicated by the stars, but different from 94a. Clone 1350 from the orchard is also identical to 1350 from the containe pots and the same holds for clone 140 . The bandmap can be used as a future reference, in finding the best combination of markers to distinguish among two or more clones. To distinguish between clones 61 and 427, bands A1 8.6 and A19.1 could be used, which are present in 427 and absent in 61 , or bands $9.1, A 8.1$ and A18.7, which are absent in 427 and present in 61 . Only one clone-specific marker was found; band A18.4 is absent in clone 69 .

\section{Discussion}

The average number of polymorphic bands amplified per 10-mer primer in Sitka spruce (four) was not very different from the number found in Black spruce (3.8) and White spruce (5.2) (Mosseler et al., 1992), although Bucci \& Menozzi (1993) found an average of 9.7 polymorphic bands in Norway spruce. According to Bucci \& Menozzi (1993) the larger number of amplification products in Norway spruce might result from a larger genome size. They found $29 \mathrm{pg}$ per haploid genome in Norway spruce, whereas White spruce had $17 \mathrm{pg}$ per haploid genome (Carlson et al., 1991). The genome size of Sitka spruce is not known. Although the genome size is only one of the several contributory factors affecting the number of amplification products, others being constitution of amplification mix, thermal cycling, sensitivity of gel staining system etc., the genome size of Sitka spruce could be comparable to that of White spruce.

RAPD markers proved to be consistent in clonally produced ramets of Sitka spruce clones, which makes them very useful for clonal identification. However, within clone 94 two different banding patterns were found, represented by two and three ramets, which were morphologically indistinguishable. Two possible explanations for this are: (1) the rootstock has taken over from the graft, or (2) some ramets were mislabelled. If the rootstock had taken over from the graft this should be visible as the rootstock is seedling material and has a different needle morphology from mature trees (W. Brown, pers. comm.), which was not observed. Also one would not expect that two or three seedlings, obtained after open-pollination, would have identical banding patterns for each of six 10-mer primers. It seems most likely that some of the ramets were mislabelled. According to Wheeler \& Jech (1992) mislabelling of orchard ramets is relatively common, and in surveying 20 ramets of a Loblolly pine clone four distinct multilocus genotypes were found. From 


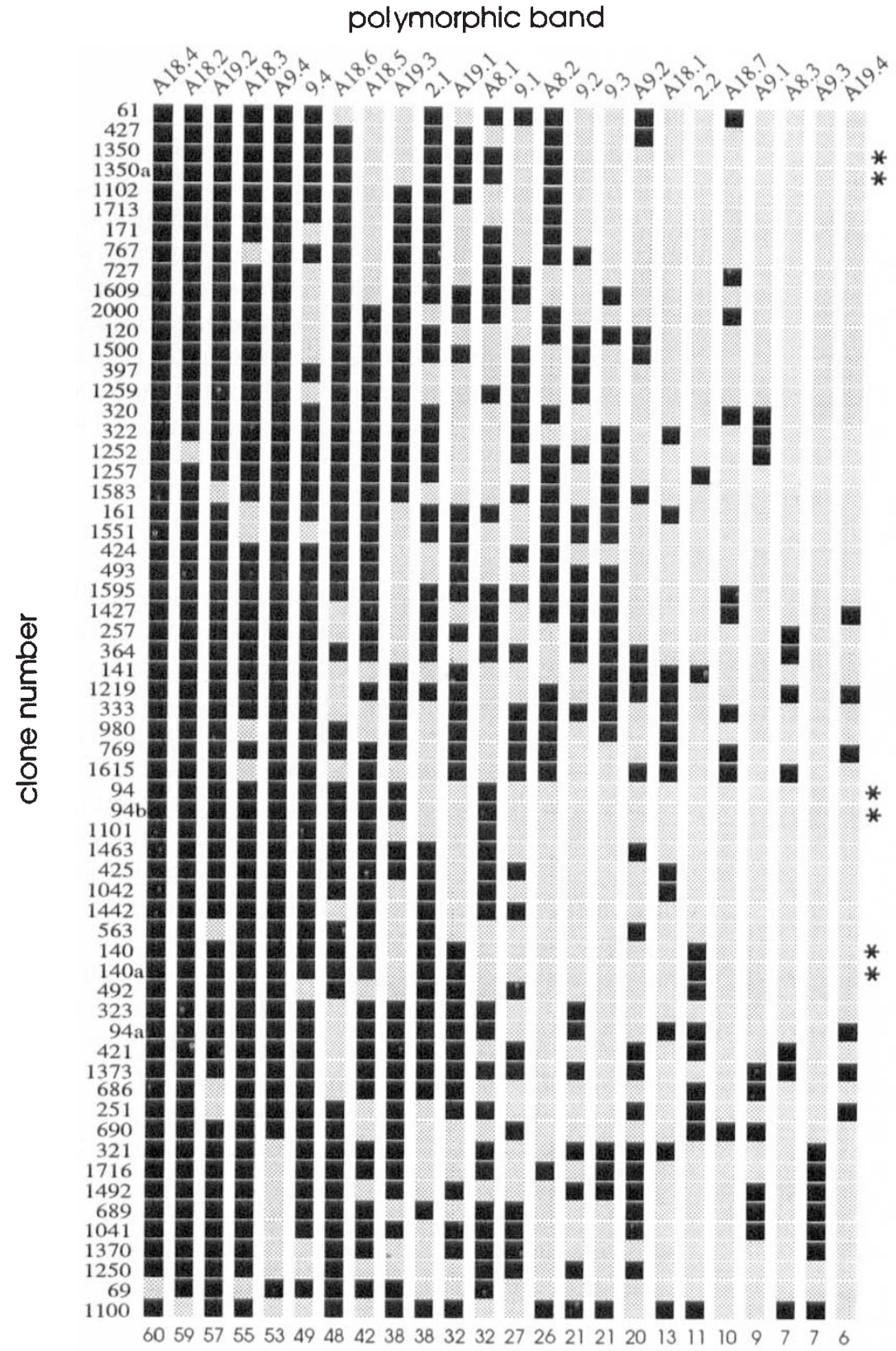

band frequency
Fig. 3 'Bandmap' of polymorphic amplified bands. A total of 24 polymorphic bands were generated (top), represents the presence of a band and no band present. Numbers on the left represent the individual Sitka spruce clones studied. The frequency of each band occurring within this set of clones is indicated by the numbers at the bottom and the stars on the right indicate instances where two adjacent clones are in fact identical with respect to the bands in the bandmap. Additional information is given in the text.
2-13 per cent of mislabelled ramets have been identified through the use of isozymes in several tree seed orchards (Harju \& Muona, 1989; Wheeler \& Jech, 1992). Correct identification of ramets of clones in a seed orchard should be carried out at the time of orchard establishment, when trees are easy to remove, and certainly well before orchard production or breeding. The long-term costs of mislabelling can be significant and will increase as improvement programmes move though generations (Wheeler \& Jech, 1992).

Hamrick \& Godt (1990) found gymnosperms to be among the most genetically variable of plant species.
Within spruce species genetic variation seems high based both on isozyme (Yeh \& El-Kassaby, 1980; Yeh et al., 1986; Alden \& Loopstra, 1987) and DNA studies (Mosseler et al., 1992; Tulsieram et al., 1992). High levels of genetic variation are important to safeguard against biotic and nonbiotic factors, especially in long-lived crops such as trees. All the Sitka spruce clones analysed are part of the breeding pool and, with one exception, joined together at 60 per cent similarity (Fig. 2). The variation within superior Sitka spruce clones seems high but lower than the variation within natural populations of Sitka spruce, which Yeh \& El- 
Kassaby (1980) found to be 92 per cent using isozyme data.

All the 57 Sitka spruce clones analysed could be identified using a combination of six 10 -mer primers, which was not possible using six isozyme systems (Cottrell \& White, pers. comm.). A minimum of four primers was required to distinguish all clones. Thus, our results show that RAPD markers are effective tools for distinguishing among individuals and are more polymorphic than isozymes, which corresponds with the results of Kremer et al. (1992) using oak and Lui \& Furnier (1993) with aspen.

RAPD markers were shown to be useful in detecting variability in Sitka spruce and for identification of Sitka spruce clones. Furthermore, mislabelled ramets could be identified. We further wish to use these RAPD markers to investigate mislabelling and outcrossing in Sitka spruce seed orchards.

\section{Acknowledgements}

The authors thank the Scottish Office, Agricultural and Fisheries Department for funding this work, J. E. Cottrell, G. I. Forrest, A. M. Fletcher and D. Rook at the Forestry Authority for guidance and access to their tree plantation, C. Hackett from Scottish Agricultural Statistics Service for statistical guidance, and L. Ross for technical assistance.

\section{References}

ADAMS, w. T. AND JOLY, R. J. 1980. Allozyme studies in Loblolly pine seed orchards; clonal variation and frequency of progeny due to self fertilization. Silvae Genet., 29, 1-4.

ALDEN, J. AND LOOPSTRA, C. 1987. Genetic diversity and population structure of Picea glauca on an altitudinal gradient in interior Alaska. Can. J. Forest Res., 17, 1519-1526.

BOUSOUET, J., SIMON, L. AND LALONDE, M. 1990. DNA amplification from vegetative and sexual tissues of trees using polymerase chain reaction. Can. J. Forest Res., 20, 254-257.

BUCCI, G. AND MENOZZI, P. 1993. Segregation analysis of random amplified polymorphic DNA (RAPD) markers in Picea abies Karst. Mol. Ecol., 2, 227-232.

CARLSON, J. E., TUlSIERAM, L. K., GLAUBiTZ, J. C., LUK, V. W. K., KAUFFELDT, C. AND RUTLEDGE, R. 1991. Segregation of random amplified DNA markers in $F_{1}$ progeny of conifers. Theor. Appl. Genet., 83, 194-200.

D'OVIDIO, R., TANZARELlA, O. A. AND PONCEDDU, E. 1990. Rapid and efficient detection of genetic polymorphism in wheat through amplification by polymerase chain reaction. Plant Mol. Biol., 15, 169-171.

FORREST, G. I. 1994. Biochemical markers in tree improvement programmes. Forestry Abstracts, 55, 123-153.

GRAHAM, J., McNICOL, R. J., GREIG, K. AND VAN DE VEN, W. T. G. 1994. Identification of red raspberry cultivars and an assessment of their relatedness using fingerprints produced by random primers. J. Hort. Sci., 69, 123-130.

HAMRICK, J. L. AND GODT, M. J. w. 1990. Allozyme diversity in plant species. In: Brown, A. H. D., Clegg, M. T., Kahler, A. L. and Weir, B. S. (eds) Plant Population Genetics, Breeding and Genetic Resources, pp. 43-63. Sinauer Associates, Sunderland, MA.

HARJU, A. AND MUONA, o. 1989. Background pollination in Pinus sylvestris L. seed orchards. Scand. J. Forest Res., 4, 413-520.

HELENTJARIS, T. AND BURR, B. 1989. Development and Application of Molecular Markers to Problems in Plant Genetics. Cold Spring Harbor Laboratory Press, Cold Spring Harbor, NY.

KARVONEN, P. AND SAVOLAINEN, O. 1992. rDNA variation in Scots pine (Pinus sylvestris L.). Abstracts of Molecular Biology of Forest Trees, Fifth Workshop of the IUFRO Working Party Molecular Genetics and Cytogenetics, Carcans-Maubuisson, 15-18 June, 1992.

KREMER, A., MOREAU, F., PETIT, R., ZANETTO, A., BACILIERI, R. AND DUCousso, A. 1992. Comparison of interspecific variation in European oaks based on allozymes, cpDNA, rDNA and RAPD's. Abstracts of International Symposium on Population Genetics and Gene Conservation of Forest Trees, Joint Meeting of IUFRO Working Parties Biochemical Genetics, Population and Ecological Genetics and Subject Group: Provenances, Breeding and Genetic Resources, Carcans-Maubuisson, 24-28 August, 1992.

LUI, Z. AND FURNIER, G. R. 1993. Comparison of allozyme, RFLP, and RAPD markers for revealing genetic variation within and between trembling aspen and bigtooth aspen. Theor. Appl. Genet., 87, 97-105.

MOREAU, F., KREMER, A., MOREAU, P. AND PETIT, R. 1992. Intraand interspecific variation of random amplified DNA fragments in European oaks. Abstracts of Molecular Biology of Forest Trees, Fifth Workshop of the IUFRO Working Party Molecular Genetics and Cytogenetics, Carcans-Maubuisson, 15-18 June, 1992.

MORGANTE, M., VENDRAMIN, G. G. AND OLIVIERI, A. M. 1992. Isolation of molecular markers in Pinus leucodermis Ant. using random amplified polymorphic DNA's. Abstracts of Molecular Biology of Forest Trees, Fifth Workshop of the IUFRO Working Party Molecular Genetics and Cytogenetics, Carcans-Maubuisson, 15-18 June, 1992.

MOSSELER, A., EGGER, K. N. AND HUGHES, G. A.1992. Low levels of genetic diversity in red pine confirmed by random amplified polymorphic DNA markers. Can. J. Forest Res., 22, 1332-1337.

NEI, M. AND LI, W.-H. 1979. Mathematical model for studying genetic variation in terms of restriction endonucleases. Proc. Natl. Acad. Sci. U.S.A., 76, 5269-5273.

NYBOM, H., ROGSTAD, S. H. AND SCHAAL, B. A. 1990 . Genetic variation detected by use of the M13 'DNA fingerprint' probe in Malus, Prunus and Rubus (Rosaceae). Theor. Appl. Genet., 79, 153-156.

POWELL, W., PHILliPS, M. S., McNICOL, J. W. AND WAUGH, R. 1991. The use of DNA markers to estimate the extent and nature of genetic variability in Solanum tuberosum cultivars. Ann. appl. Biol., 118, 423-432. 
ROOK, D. 1992. Super Sitka for the 90's. Forestry Commission Bulletin, 103, 75 pp.

SKOV, E. AND WELLENDORF, H. 1992. Application of RAPD for high-density genome-mapping and marker-aided selection in Norway spruce. Abstracts of Molecular Biology of Forest Trees, Fifth Workshop of the IUFRO Working Party Molecular Genetics and Cytogenetics, Carcans-Maubuisson, 15-18 June, 1992.

TULSIERAM, L. K., GLAUBITZ, J. C., KISS, G. AND CARLSON, J. E. 1992. Single tree genetic linkage mapping in conifers using haploid DNA from megagametophytes. Bio/Technology, 10, 686-690.

VOLKAERT, H., HUTCHISON, K. W. AND GREENWOOD, M. S. 1992. Detection of highly polymorphic DNA sequences and its use in forestry. Abstracts of Molecular Biology of Forest Trees, Fifth Workshop of the IUFRO Working Party Molecular Genetics and Cytogenetics, Carcans-Maubuisson, 15-18 June, 1992.
WHEELER, N. C. AND JECH, K. S. 1992. The use of electrophoretic markers in forest research. New Forests, 6, 311-328.

WILDE, J., WAUGH, R. AND POWELL, W. 1992. Genetic fingerprinting of Theobroma clones using randomly amplified polymorphic DNA markers. Theor. Appl. Genet., 83, 871-877.

WILLIAMS, J. G. K., KUBELIK, A. R., LIVAK, K. J., RAFALSKI, J. A. AND TINGEY, s. v. 1990. DNA polymorphisms amplified by arbitrary primers are useful as genetic markers. $\mathrm{Nucl}$. Acids Res., 18, 6531-6535.

YEH, F. C. AND EL-KASSABY, Y. A. 1980. Enzyme variation in natural populations of Sitka spruce (Picea sitchensis). 1. Genetic variation patterns among trees from 10 IUFRO provenances. Can. J. Forest Res., 10, 214-215.

YEH, F. C., KHALIL, M. A. K., EL-KASSABY, Y. A. AND TRUST, D. C. 1986. Allozyme variation in Picea mariana from Newfoundland: genetic diversity, population structure, and analysis of differentiation. Can. J. Forest Res., 16, 713-720. 